\title{
Estimating the Amount of Eroded Section in a Partially Exhumed Basin from Geophysical Well Logs: An Example from the North Slope
}

\author{
By W. Matthew Burns, Daniel O. Hayba, Elisabeth L. Rowan, and David W. Houseknecht
}

\section{Abstract}

The reconstruction of burial and thermal histories of partially exhumed basins requires an estimation of the amount of erosion that has occurred since the time of maximum burial. We have developed a method for estimating eroded thickness by using porosity-depth trends derived from borehole sonic logs of wells in the Colville Basin of northern Alaska. Porosity-depth functions defined from sonic-porosity logs in wells drilled in minimally eroded parts of the basin provide a baseline for comparison with the porosity-depth trends observed in other wells across the basin. Calculated porosities, based on porosity-depth functions, were fitted to the observed data in each well by varying the amount of section assumed to have been eroded from the top of the sedimentary column. The result is an estimate of denudation at the wellsite since the time of maximum sediment accumulation. Alternative methods of estimating exhumation include fission-track analysis and projection of trendlines through vitrinite-reflectance profiles. In the Colville Basin, the methodology described here provides results generally similar to those from fission-track analysis and vitrinite-reflectance profiles, but with greatly improved spatial resolution relative to the published fission-track data and with improved reliability relative to the vitrinite-reflectance data. In addition, the exhumation estimates derived from sonic-porosity logs are independent of the thermal evolution of the basin, allowing these estimates to be used as independent variables in thermal-history modeling.

\section{Introduction}

Burial- and thermal-history modeling of partially exhumed sedimentary basins (that is, basins in which the sedimentary fill has been partly removed by erosion) requires an estimation of the amount of section deposited and later eroded at all modeled sites. The Colville Basin, which spans the Alaskan North Slope (fig. 1), has undergone substantial exhumation since the time of maximum burial, as indicated by stratigraphic evidence, vitrinite-reflectance profiles, and fission-track data analysis. None of these datasets, however, is sufficient to define the amount of exhumation that occurred at the basin scale. Extensive regional exhumation, including removal of entire geologic formations across much of the basin, makes any reconstruction of the basin's stratigraphy by projection of preserved strata across the eroded areas impossible, whereas estimates of the amount of exhumation from fission-track thermochronology or vitrinite-reflectance profiles have only a limited value for basin studies, owing to restricted availability of fission-track data and inconsistent results from vitrinite-reflectance data. Moreover, exhumation estimates derived from thermal-history modeling, such as from fissiontrack and vitrinite-reflectance data, create an interdependence between the burial- and thermal-history components of basin models and may increase the uncertainty of model results.

As an alternative approach to the use of fission-track and vitrinite-reflectance data for estimating exhumation in the Colville Basin, we have developed a method based on a comparison of regional porosity-depth trends in well data. This approach provides increased spatial resolution relative to fission-track data and increased consistency relative to vitrinitereflectance data. Furthermore, it allows us to define the burial history as an independent variable within the thermal-history model, thereby simplifying the modeling process and reducing uncertainty in model results.

\section{Approaches to Assessing Exhumation in the Colville Basin}

Contractional deformation of Colville Basin fill in the Brooks Range foothills (fig. 1) has led to obvious denudation where high-relief structures created topographic relief (see approximate north limit of high-relief structures, fig. 1). Stratigraphic thicknesses measured in outcrops and from subsurface data can be projected across the eroded structures to estimate 
the amount of denudation that has occurred. Broad structural thickening of ductile, shale-rich formations, however, extends far northward of the zone of high-relief structures (T. Moore, written commun., 2005) and probably resulted in more widespread surface uplift and denudation. Furthermore, the high vitrinite reflectances measured in outcrops and near-surface samples from undeformed areas of the basin (Johnsson and others, 1999) suggest that exhumation also occurred in parts of the North Slope that have not undergone significant tectonic shortening. Apatite fission-track analyses confirm that exhumation has occurred across most of the Colville Basin and indicate that as much as $\sim 5,500 \mathrm{ft}$ of basin fill may have been removed from some undeformed areas (for example, O'Sullivan, 1996), suggesting that exhumation occurred on a regional scale. Thus, simple stratigraphic projections across individual structures provide a measure of only local differences in exhumation.

Alternative methods to stratigraphic projection for determining the amount of exhumation in a sedimentary basin generally rely on thermal-history modeling, in particular, fissiontrack and vitrinite-reflectance data (for example, Armagnac and others, 1989; Bray and others, 1992; Dow, 1977; Green and others, 1995). Both fission-track and vitrinite-reflectance data can be used as maximum temperature indicators, and so the downhole trend through maximum temperature estimates derived from either fission-track or vitrinite-reflectance data approximates the paleothermal gradient at the time of maximum heating/burial. Projection of this gradient to the estimated surface temperature at the time of maximum burial provides an estimate of the amount of section removed.

Fission-track thermochronology (for example, O'Sullivan, 1996, 1999) and vitrinite-reflectance profiles (Armagnac and others, 1989) have been used in previous studies of exhumation in the Colville Basin; however, the published exhumation estimates from both fission-track and vitrinite-reflectance data are too sparse for confident regional interpolation and application in a basinwide burial-history model. Nonetheless, additional vitrinite-reflectance measurements on dispersed vitrinite that are available for numerous wells on the North Slope (Johnsson and others, 1999) could serve as a source of the basinwide estimates of exhumation that are needed for modeling. In many wells across the North Slope, however, the measured vitrinite reflectances appear to reflect deposition of recycled vitrinite (Houseknecht and Hayba, 1998). Therefore, reflectance-depth trends are difficult to interpret and, in many places, probably do not represent the

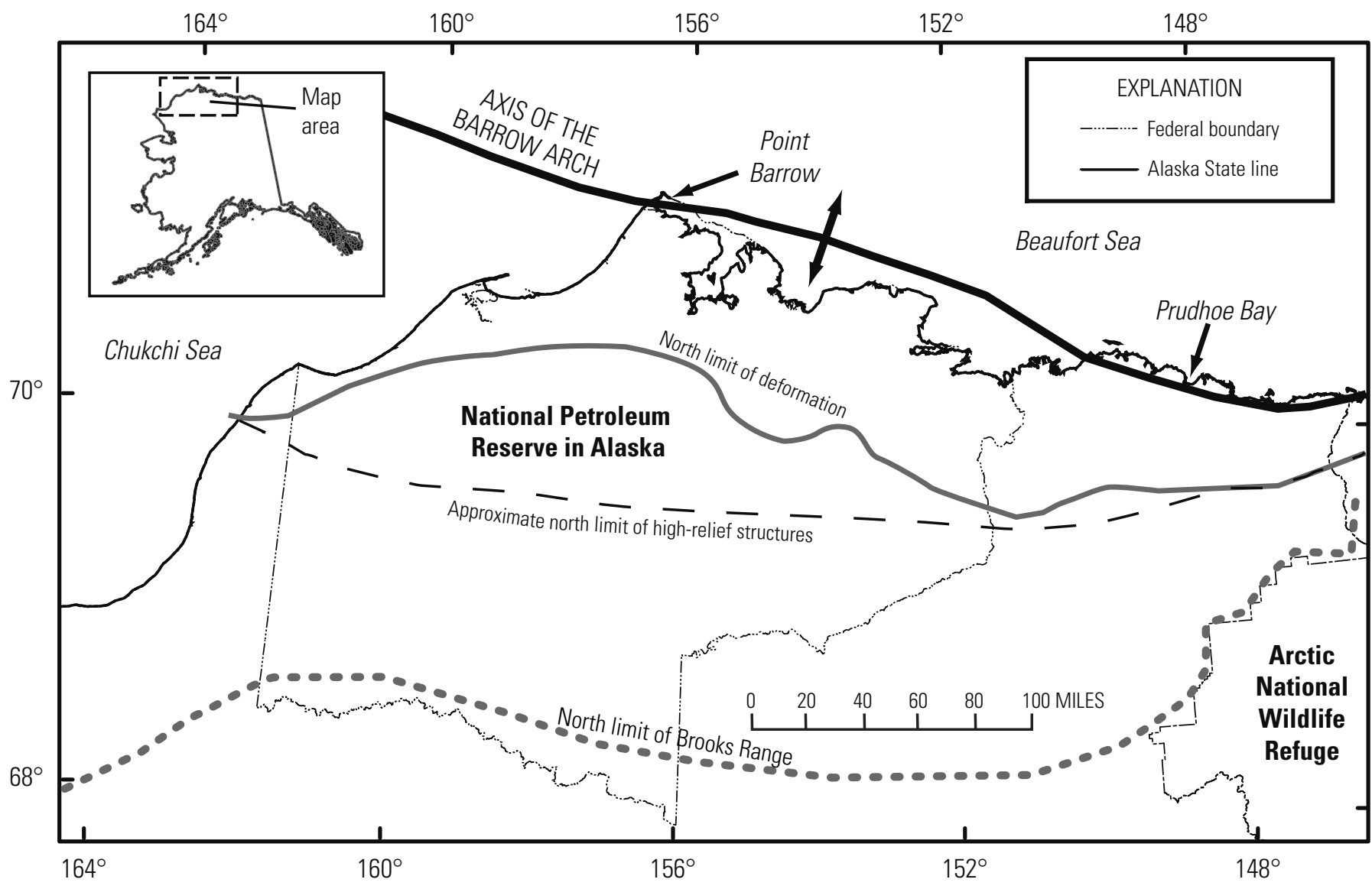

Figure 1. Alaskan North Slope, showing locations of study area and key geographic and geologic features. North limit of deformation from T. Moore (written commun., 2005). 
true paleothermal gradient, reducing their usefulness as guides to the amount of exhumation that has occurred.

Additionally, multiple and conflicting vitrinite-reflectance datasets exist for many wells, increasing the uncertainty in exhumation estimates calculated from vitrinite-reflectance profiles. In a particularly extreme example (fig. 2), two vitrinite-reflectance datasets for the same well, but obtained by different laboratories, result in erosion estimates that differ by thousands of feet. The cause of such disagreements between vitrinite-reflectance datasets for North Slope wells is unclear. As a result, determination of preferred reflectance-depth trends in these wells is ambiguous. Moreover, such marked disagreement between datasets for the same well suggests that vitrinite-reflectance datasets for the North Slope should generally be regarded with skepticism.

Finally, the use of either fission-track or vitrinite-reflectance data to define the amount of exhumation in a basin can complicate burial/thermal-history modeling and increase the uncertainty of model results. Amounts of exhumation and the corresponding burial histories derived from paleotemperature indicators (that is, fission-track and vitrinite-reflectance data) will be dependent variables when applied within a thermal-his-

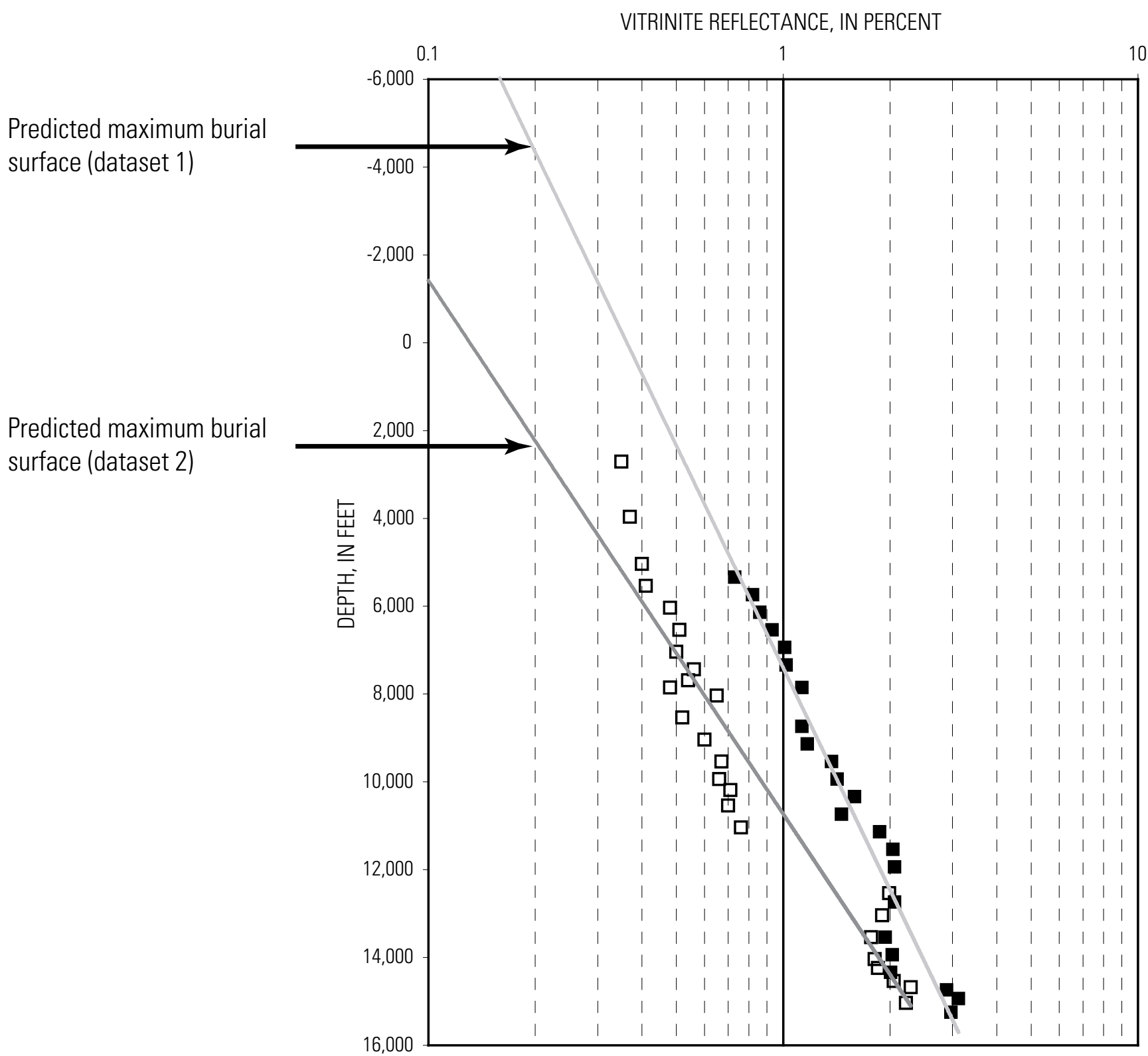

Figure 2. Vitrinite reflectance versus depth in the Itkillik River Unit 1 well on the Alaskan North Slope (fig. 1). Single best-fit trendlines are projected through two apparently conflicting vitrinite-reflectance datasets to predicted maximum-burial surfaces corresponding to $R_{0}=0.2$ percent. Implied depths of burial and exhumation based on the two datasets differ by thousands of feet. 
tory model because the amount of inferred exhumation will vary with the assumed values of thermal parameters (that is, thermal gradient, thermal conductivity, heat flow). Thus, the accuracy of burial- and thermal-history models is limited by the typically large uncertainties in paleoheat flow and thermal conductivity (see Deming and others, 1990). For the purposes of burial/thermal-history modeling, we would prefer that the amount of exhumation and, therefore, the maximum burial depth be determined independently from thermal parameters.

\section{Estimating Amount of Exhumation from Porosity Logs}

To avoid the problems with fission-track and vitrinite-reflectance methods, we have developed an alternative methodology for estimating amount of exhumation, based on an analysis of porosity-depth trends in sonic-porosity logs. Owing to the largely irreversible effect of sediment compaction (for example, Hedberg, 1936; Magara, 1980), porositydepth trends in well data can be used to estimate the amount of missing sedimentary section in areas that have undergone significant erosion. Although core-porosity measurements are typically made for only a small part of the total sedimentary section penetrated in a well, various commonly acquired geophysical logs can be used to estimate porosity for the entire borehole. Most notably, sonic-transit-time logs have been used to determine downhole porosity specifically as a means of defining shale-compaction trends for estimating erosion (for example, Magara, 1976; Issler, 1992; Nelson and Bird, 2005).

Numerous empirical transforms relate sonic velocity to porosity in sedimentary rocks. Nelson and Bird (2005) reviewed several of these transforms and noted that the acoustic formation factor defined by Raiga-Clemenceau and others (1988) provides a relatively accurate means of calculating porosity $(\phi)$ from sonic transit time $(t)$ as a function of rock type:

$$
\phi=1-\left(\frac{t_{\mathrm{ma}}}{t}\right)^{\frac{1}{x}},
$$

where $t_{\mathrm{ma}}$ is the sonic transit time for the rock matrix at zero porosity and $x$ is an exponent specific to the matrix lithology. Issler (1992) adopted this approach for defining porosity in shales in the Beaufort-Mackenzie Basin of northern Canada, and the compaction curves derived from those porosities became the basis for estimating the amount of erosion that had occurred in different parts of the basin. Issler defined a reference compaction (porosity-depth) curve from sonicporosity logs in a part of the basin that has undergone little or no erosion and compared that curve with the sonic-porosity logs in wells within other parts of the basin. The vertical offset between the reference curve and the sonic-porosity logs represents the amount of erosion that has occurred at each wellsite.

Working with well data from the Alaskan North Slope and the Beaufort Sea, Rowan and others (2003) expanded upon Issler's (1992) use of the acoustic formation factor (Raiga-Clemenceau and others, 1988) for defining compaction curves from sonic-porosity logs, incorporating not only shale but also all siliciclastic rocks. Rowan and others normalized gamma-ray logs for each well to create shale-fraction $\left(v_{\text {shale }}\right) \operatorname{logs}$, which provide a measure of the lithology for each sonic-transit-time measurement. Combining shale-fraction logs and the corresponding sonic-transit-time logs from wells in the noneroded offshore part of the basin, they determined matrix transit times (52 and $67 \mathrm{~ms}$ ) and $x$ values (2.05 and 2.19) for shale and sandstone end members, respectively. They then calculated sonic-porosity logs, using these parameters in conjunction with sonic-transit-time logs for 19 wells in offshore and coastal areas where stratigraphic evidence indicates that erosion is minimal, and used these sonic-porosity logs as a basis for defining compaction curves for the basin. They edited the logs to remove invalid porosities caused by permafrost and borehole washouts; also, they excluded zones of undercompacted sediment caused by pore-fluid overpressuring to improve the resolution of normal compaction trends in the data. Finally, they used only the sections of the logs corresponding to the Brookian megasequence (Cretaceous and Tertiary age) to define compaction trends in order to avoid potential differences in porosity trends across the underlying Lower Cretaceous unconformity. The edited logs were compiled by rock type, allowing a definition of compaction curves that represent the porosity-depth behavior of sandstone, shale, and a nominal siltstone (that is, $v_{\text {shale }}=0.5$ ). They selected an exponential form of the equation proposed by Athy (1930) for the compaction curves:

$$
\phi_{z}=\phi_{0} \exp (-b z)
$$

where $\phi_{z}$ is the porosity fraction at depth $z, \phi_{0}$ is the initial porosity fraction, and $b$ is a variable that reflects the curvature of the porosity-depth trend. Alternative approaches to an exponential compaction curve include linear and reciprocal forms (for example, Falvey and Middleton, 1981; Hunt and others, 1998). Whereas Nelson and Bird (2005) used a two-point linear fit to represent shale porosity in a recent study of porositydepth trends on the Alaskan North Slope, Rowan and others preferred the exponential form more commonly used in basin modeling. From a visual fitting of the data, the parameters that they defined are listed in table 1.

\section{Application to the Colville Basin}

Rowan and others' (2003) compaction parameters, derived from nonexhumed parts of the Colville Basin (fig. 1), provide a frame of reference for judging the amount of exhumation that has occurred at other wellsites in the basin. A porosity-depth curve modeled from Rowan and others' parameters could be fitted to the corresponding sonic-porosity $\log$ by adjusting the datum of the modeled curve relative to the current ground surface to achieve agreement with the 
measured porosities. Given that significant sedimentation had not occurred after exhumation, the difference between the adjusted datum and the current ground surface would indicate the total stratal thickness that has been removed since the time of maximum burial.

Before the approach to estimating exhumation outlined above could be applied throughout the Colville Basin (fig. 1), we needed to construct a second set of porosity-depth curves derived from Lower Cretaceous and older strata to be used in conjunction with the porosity-depth functions of Rowan and others (2003). Maximum burial in the Colville Basin resulted from west-to-east, axial progradation of the clastic Brookian megasequence during the Cretaceous and Tertiary (Molenaar, 1985). Rowan and others' exclusive use of well data from parts of the basin that have not undergone significant exhumation since the time of maximum burial led them to prefer wells in the east half of the basin (fig. 3), where the Brookian megasequence is predominantly Late Cretaceous and Tertiary. In contrast, the Brookian megasequence in the west half of the basin is dominated by Aptian through Albian strata that appear to have followed different porosity-depth paths than the younger sedimentary rocks, possibly owing to differences in sediment composition. The calculated sonic porosity in the Nechelik 1 well is plotted against the porosity predicted by using Rowan and others' parameters in figure 4. This well, which is located adjacent to the northeastern part of the National Petroleum Reserve in Alaska (NPRA, fig. 1), penetrates a thick succession of Aptian through Albian strata capped by a thinner section of younger strata. Within the Aptian through Albian section, Rowan and others' porositydepth functions generally overestimate porosity with increasing depth. In contrast, the porosity log for overlying Upper Cretaceous through Tertiary rocks agrees closely with calculated values. In this and similar wells that sample both porosity-depth trends, Rowan and others' compaction curves can be used to determine the amount of exhumation by applying them to only the upper part of the porosity log, corresponding to Upper Cretaceous and younger strata. Most of the western

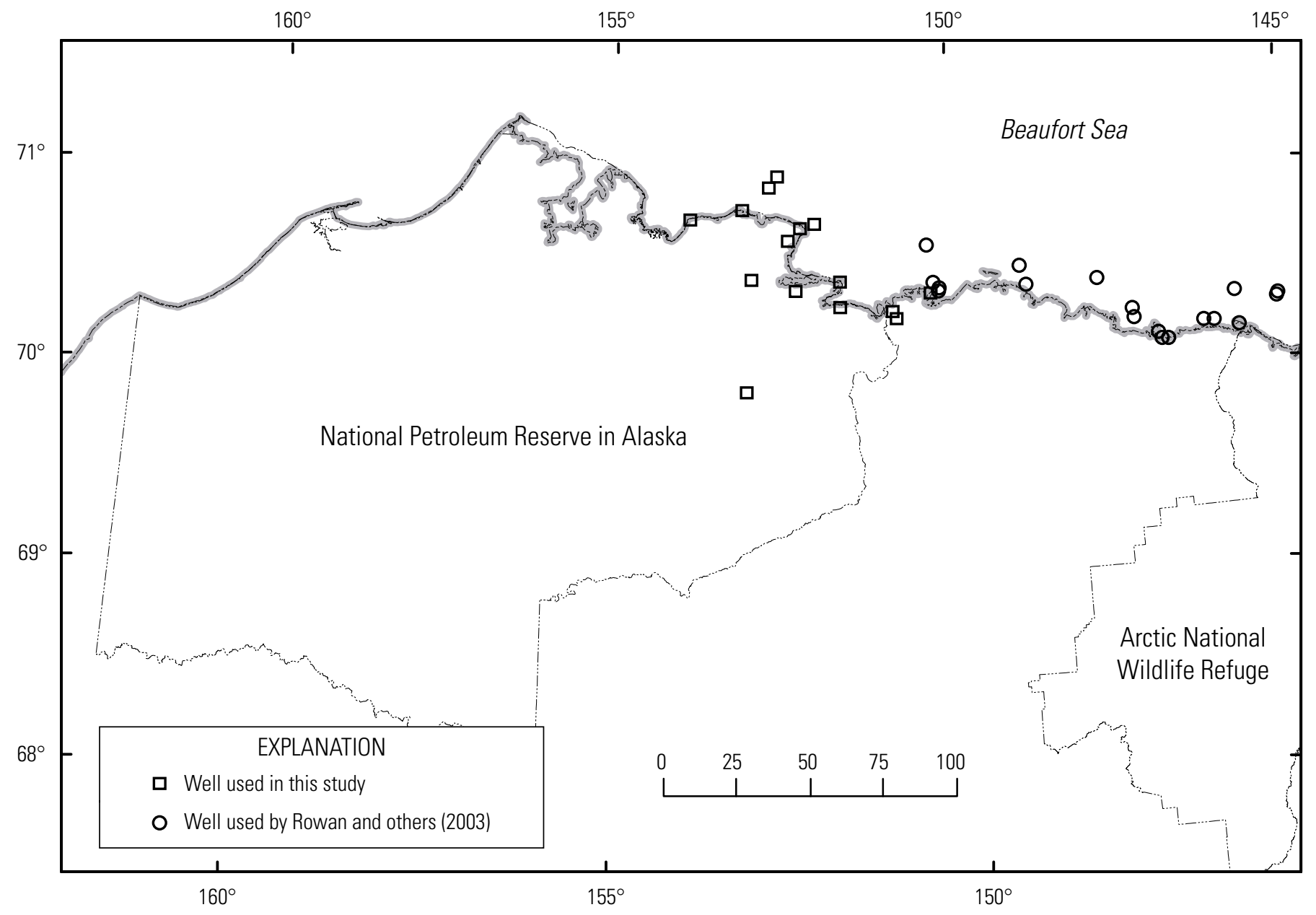

Figure 3. Alaskan North Slope, showing distribution of wells used in definition of compaction parameters by Rowan and others (2003) and in this study. 
POROSITY DIFFERENCE (PORE FRACTION)

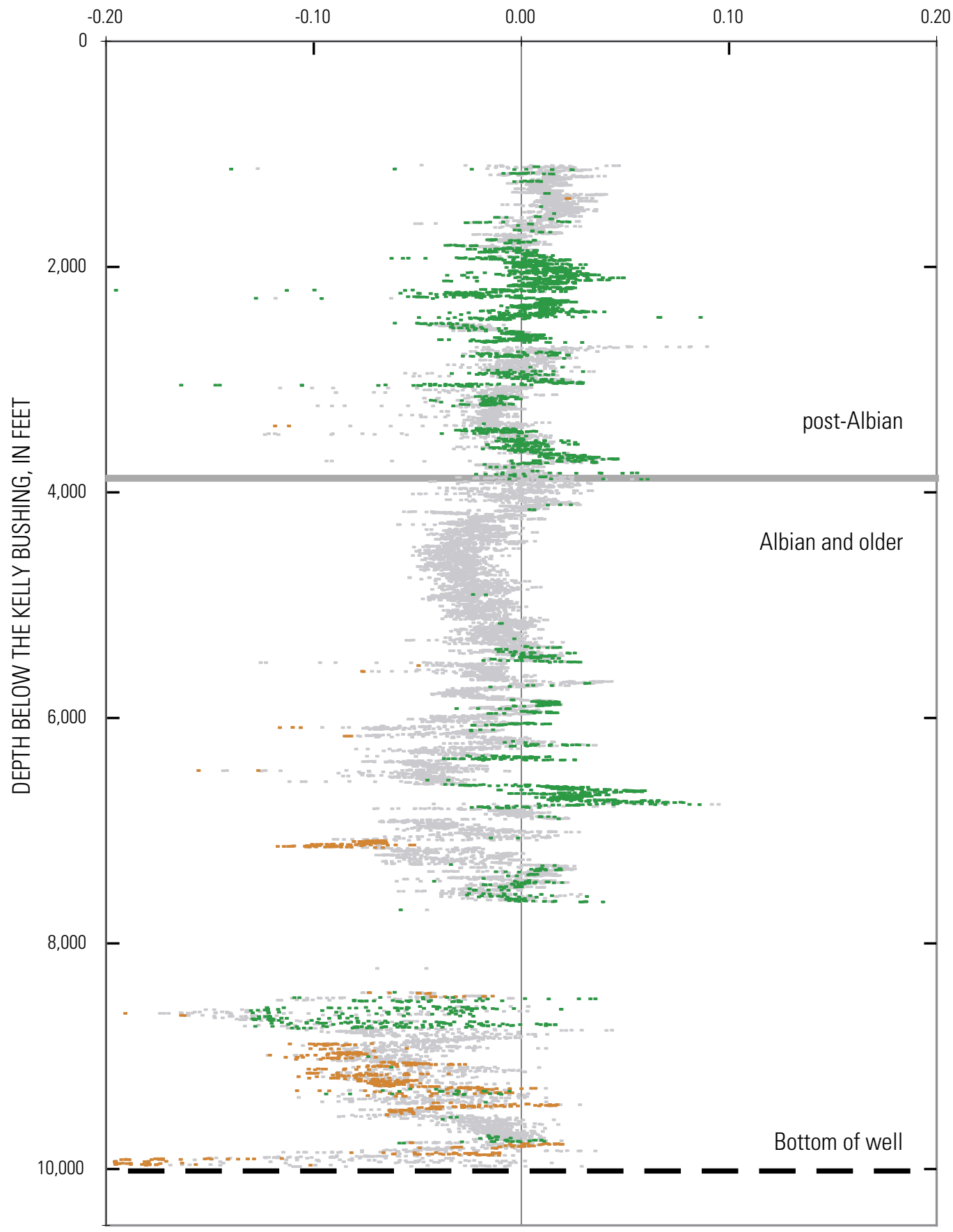

Figure 4. Difference ( $x$-value) between calculated sonic porosity and porosity predicted by using Rowan and others' (2003) porosity-depth functions versus depth below the Kelly bushing in a well on the Alaskan North Slope (fig. 1). Positive x-values occur where predicted porosity is less than calculated, and negative $x$-values where predicted porosity is greater than calculated. Orange and green markers represent pure sandstone (vshale $<0.01$ ) and shale (vshale $>0.99$ ), respectively; gray markers represent all intermediate mixtures, as defined by shale-fraction log. 
part of the Colville Basin, however, has undergone extensive to complete erosion of the Upper Cretaceous through Tertiary stratigraphic section, and so porosity-depth curves must be calibrated to pre-Upper Cretaceous strata to estimate the amount of exhumation in that area.

We defined porosity-depth curves for the Lower Cretaceous and older strata by selecting wells that penetrated the Brookian megasequence where it comprises significant thicknesses of both Upper Cretaceous through Tertiary and Aptian through Albian strata. We combined the well stratigraphy of Bird (1988a) and Nelson and others (1998) with updates by Houseknecht $(2003,2004)$. The selected wells lie primarily in the northeastern NPRA. Amounts of exhumation were estimated for 15 wells (fig. 3; see table 3 for names and exhumation estimates) by visually fitting Rowan and others' (2003) compaction curves to the shallow sections of porosity logs corresponding to Upper Cretaceous through Tertiary rocks. The lower sections of the porosity logs were then depth shifted, according to the estimated amount of exhumation, and compiled into a single dataset. According to the methodology of Rowan and others, the grouped porosity logs were sorted lithologically, as defined by the corresponding shale-fraction logs; zones of anomalous sonic porosity were identified; and the corresponding log values were removed to enhance resolution of the normal porosity-depth trends. Exponential porosity-depth curves were then defined for each of the sand (vshale $<0.01$ ), shale (vshale $>0.99$ ), and siltstone $(0.49<$ vshale $<0.51)$ end members in pre-Late Cretaceous rocks (table 2 ). The combined data were plotted for each endmember rock type along with the corresponding porosity-depth curves of Rowan and others and from this study (fig. 5). For all three rock types, the porosity-depth curves defined in this study fit the data significantly better than do Rowan and others' curves in pre-Late Cretaceous strata.

These new curves provide the means for extending the exhumation analysis into parts of the Colville Basin where Upper Cretaceous and Tertiary strata have been removed. For each of 145 wellsites across the North Slope and adjacent offshore area, we calculated and edited sonic-porosity logs for obviously invalid or anomalous values caused by permafrost, undercompaction, borehole washouts, and rock-type misidentification (fig. 6). A second set of porosities was predicted for each well, using the shale-fraction logs to define rock type and the porosity-depth data listed in tables 1 and 2 to calculate porosity as a function of rock type and depth. The calculated and predicted porosities were compared numerically and visually to achieve an approximate best fit. By adjusting the datum of the porosity-depth curves to account for the stratigraphic thickness removed by erosion, we obtained a minimum rootmean-squared error for the predicted porosity values (fig. 7). The corresponding vertical-datum shift represents an initial estimate of the amount of erosion that has occurred at the well site since the time of maximum burial. Visual assessment of the data fit allowed adjustment from the statistical best fit as needed in recognition of irregularities remaining in the edited sonicporosity logs (fig. 8). The resulting exhumation estimates are listed in table 3 .
Table 1. Compaction parameters for Late Cretaceous and younger rocks in the Colville Basin, northern Alaska

[See figure 1 for location. $\phi_{0}$, pore fraction. From Rowan and others (2003)]

\begin{tabular}{lcc}
\hline Rock type & $\phi_{\mathbf{0}}$ & $\begin{array}{c}\boldsymbol{b} \\
\left(\mathbf{f t}^{-1}\right)\end{array}$ \\
\hline Sandstone & 0.5 & 0.0000884 \\
Shale & 0.4 & 0.0001280 \\
Siltstone & 0.44 & 0.0001158 \\
\hline
\end{tabular}

Table 2. Compaction parameters for Albian andolder rocks in the Colville Basin, northern Alaska

[See figure 1 for location. $\phi_{0}$, pore fraction]

\begin{tabular}{lcc}
\hline Rock type & $\phi_{0}$ & $\begin{array}{c}\boldsymbol{b} \\
\left(\boldsymbol{f t}^{-\mathbf{1}}\right)\end{array}$ \\
\hline Sandstone & 0.45 & 0.0001280 \\
Shale & 0.62 & 0.0002286 \\
Siltstone & 0.48 & 0.0001524 \\
\hline
\end{tabular}

\section{Validation of Results}

The absolute validity of the exhumation estimates for the Colville Basin (fig. 1) presented here cannot be verified in most places, owing to lack of a true reference value for comparison, although more qualitative analyses of validity are possible. A computer-contoured exhumation map of the Colville Basin (fig. 9) was created by interpolation of the exhumation estimates listed in table 3, using an inverse-distance-weighted algorithm. Moderate and consistent variation between adjacent wellsites produces smooth, regular gradients across the study area (fig. 1), with little evidence of disagreement between adjacent wellsites. Although an explanation of the causes of these exhumation patterns is beyond the scope of this chapter, the trends shown in figure 9 are consistent with basin morphology and stratigraphy. For example, the maximum denudation is calculated in the deformed southern part of the basin (see north limit of deformation, fig. 1), where exhumation is expected to be the greatest. Conversely, minimum exhumation is calculated in the northwestern and northeastern parts of the basin, both of which represent Tertiary depocenters where stratigraphic and fission-track data indicate that deposition was ongoing during exhumation of the basin to the south (Grantz and May, 1988; Bird and Molenaar, 1992; Sherwood and others, 1998; O’Sullivan, 1999). In addition, exhumation is shown to increase westward along the coastline of NPRA toward Point Barrow (fig. 1), coinciding with shallowing of the Barrow arch, a well-defined structural feature that existed during deposition of the Brookian megasequence (fig. 1; Bird and Molenaar, 1992). Seismic and well data clearly demonstrate erosional truncation of Brookian strata in the Point Barrow 
SONIC POROSITY (PORE FRACTION)
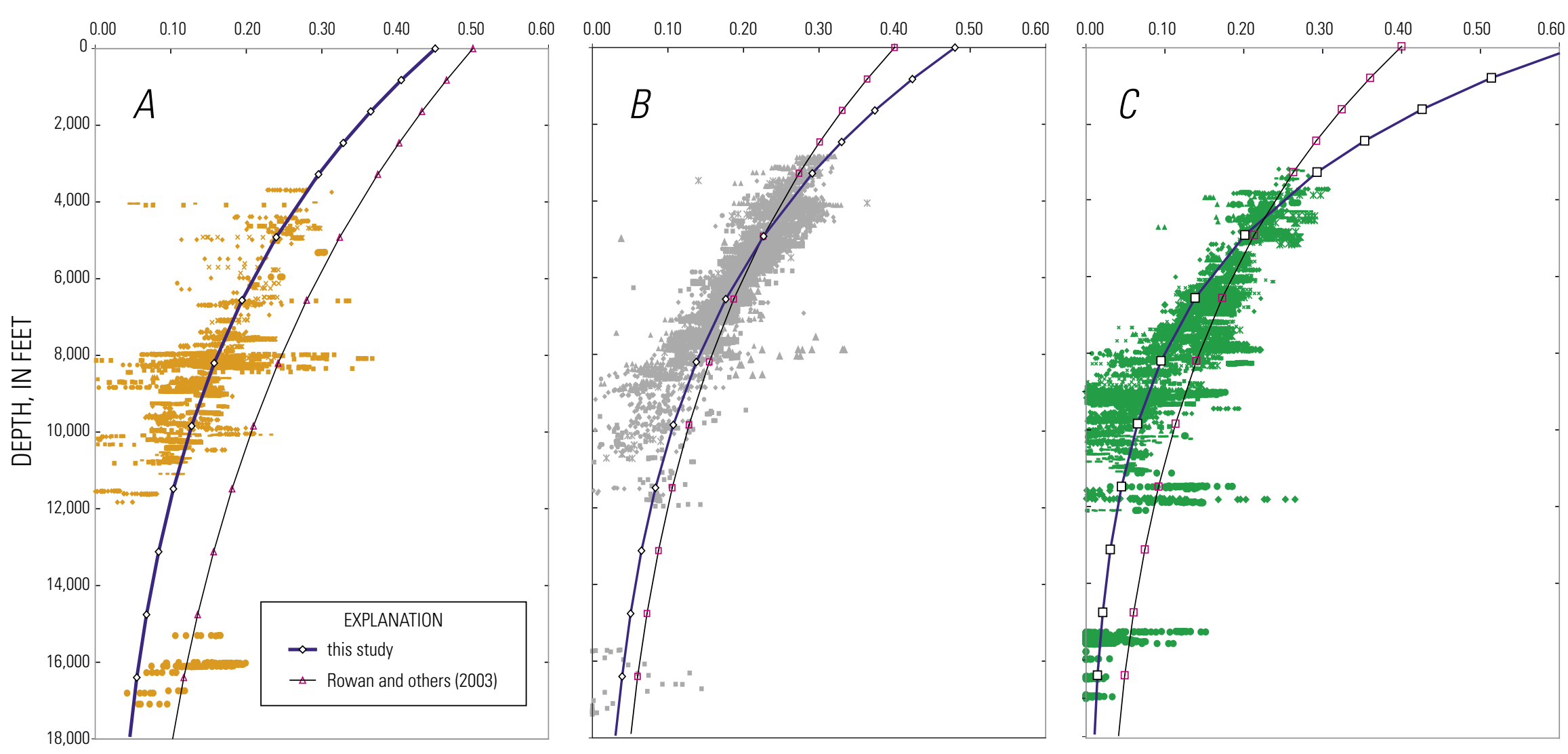

$\infty$

Figure 5. Composite sonic porosity versus depth for sand (vshale $<0.01)$, siltstone $(0.49<v$ shale $<0.51)$, and shale (vshale $>0.99$ ) lithologic end members in Albian and older strata, with corresponding porosity-depth curves from Rowan and others (2003) and this study. Data from 15 wells shown in figure 3 and listed in table 3. 
area, where the Barrow arch reaches its shallowest levels (for example, Bird and Andrews, 1979; Bird, 1988b).

For a more quantitative perspective on the validity of logderived exhumation estimates, we examined borehole stratigraphy from closely spaced wellsite pairs for evidence of the relative amount of exhumation. Although regional variations in the stratigraphic thickness of the Brookian megasequence make a basinwide assessment of relative exhumation difficult and uncertain, local variations in thickness are typically small enough to allow a comparison of the stratigraphic depths in adjacent wells as a measure of relative amount of exhumation. For example, in the eastern part of the study area (fig. 1), the measured depth to the base of the Brookian megasequence decreases southward from 12,364 ft subsea at the West Kavik 1 well to 3,450 ft subsea at the Kemik 1 well (Nelson and others, 1998). Assuming a constant thickness for Brookian strata between the two wells, the implied southward increase in the amount of exhumation is $~ 9,000 \mathrm{ft}$. In comparison, the exhumation estimates for these wells differ by $10,500 \mathrm{ft}$ (table 3). Given that the Brookian megasequence generally thickens southward into the Colville foredeep, the assumption of constant thickness probably results in underestimation of the difference in amount of exhumation at the two wellsites. Thus, the greater relative amount of exhumation calculated from sonic-porosity logs is a reasonable alternative. Insofar as the wells are spaced sufficiently closely - that is, within $\sim 20$ mi-to allow such comparisons, each of the exhumation estimates presented in this study has been crosschecked against stratigraphic data to ensure that the results are consistent with the geology. A few wells within the deformed part of the basin were excluded from the final analysis, owing to incompatibility of the exhumation estimates with stratigraphic constraints, possibly resulting from the preservation of relatively high porosities within thick overpressured zones. We note that the strata penetrated in wells south of the north limit of deformation (fig. 1) may have undergone structural thickening. Therefore, both the depositional stratigraphy and the original porosity-depth trends during deposition may be difficult to discern, and so the exhumation estimates in the areas of these wells are less certain than for wells in undeformed areas.

\section{SONIC POROSITY (PORE FRACTION)}
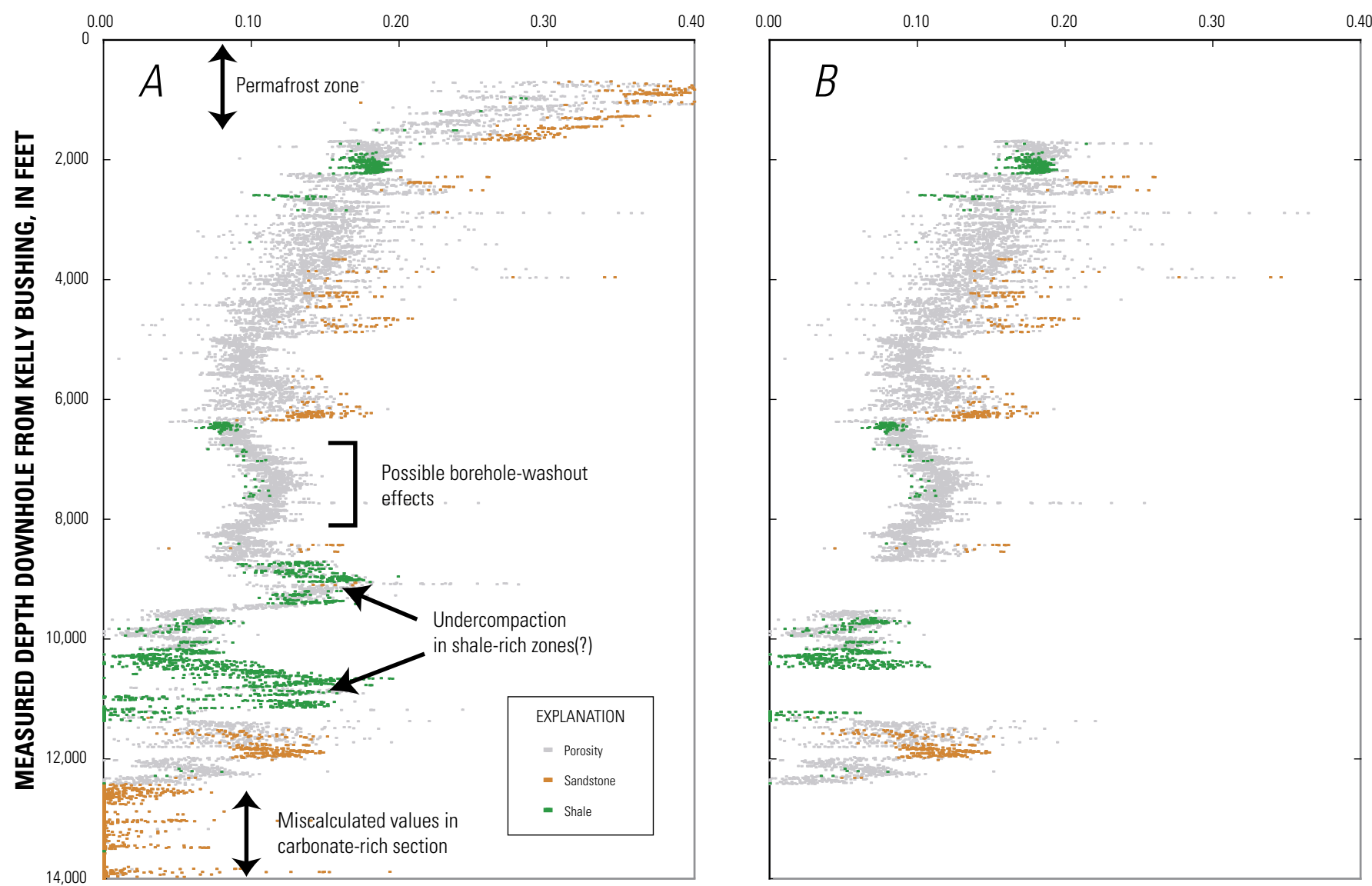

Figure 6. Example of calculated sonic-porosity data with aberrant and potentially erroneous values highlighted (A) and after editing (B). Note that relatively minor variations from expected trends were not removed to avoid biasing results of best-fit analysis. 

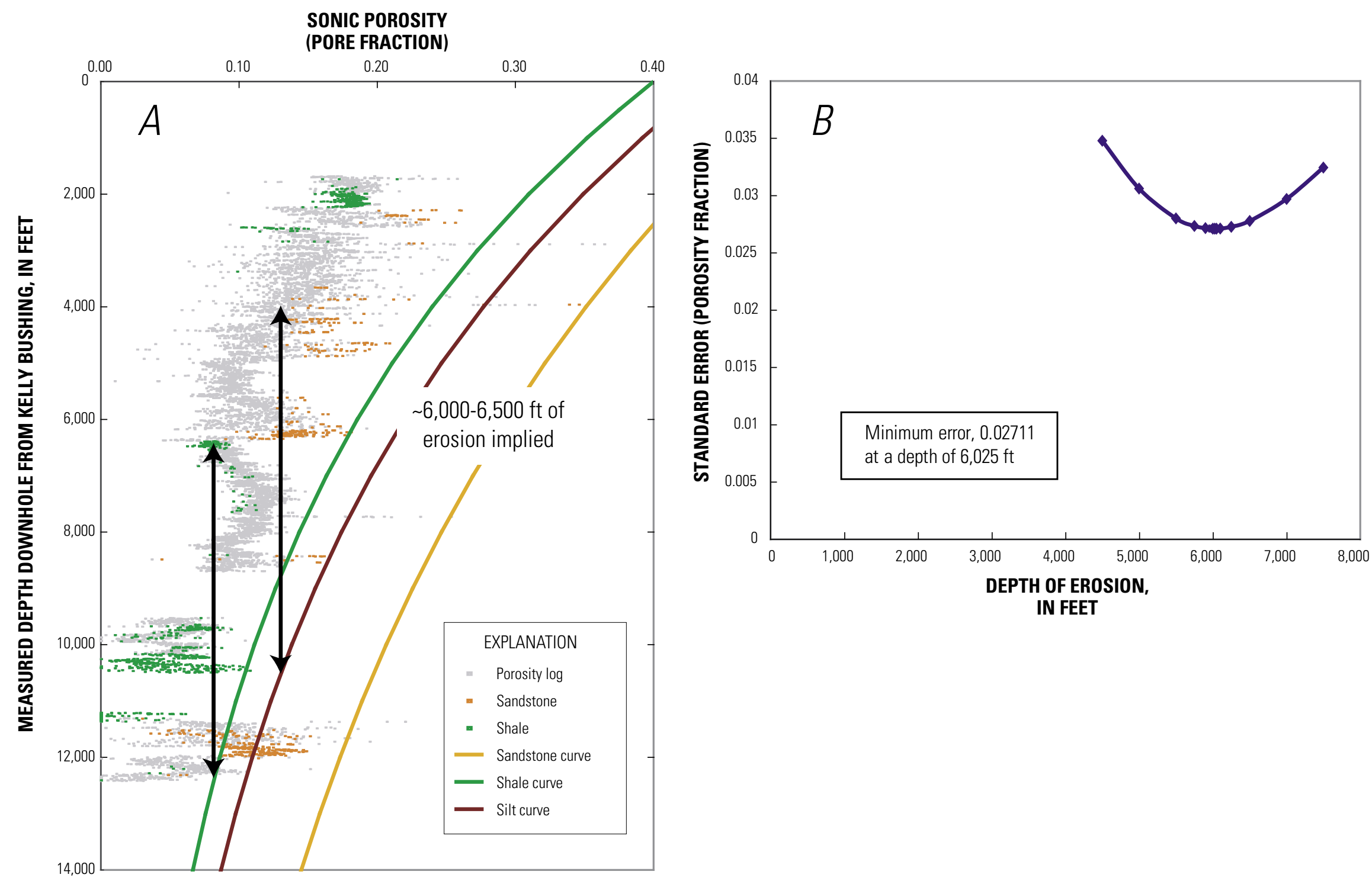

Figure 7. Visual comparison of sonic-porosity log and end-member porosity-depth curves $(A)$ allows initial estimation of amount of erosion from vertical offset of log and curves. Root-mean-square-error-minimization routine $(B)$ determines precise amount of erosion required to best fit sonic-porosity data to porosities calculated from porositydepth functions. 


\section{SONIC POROSITY (PORE FRACTION)}
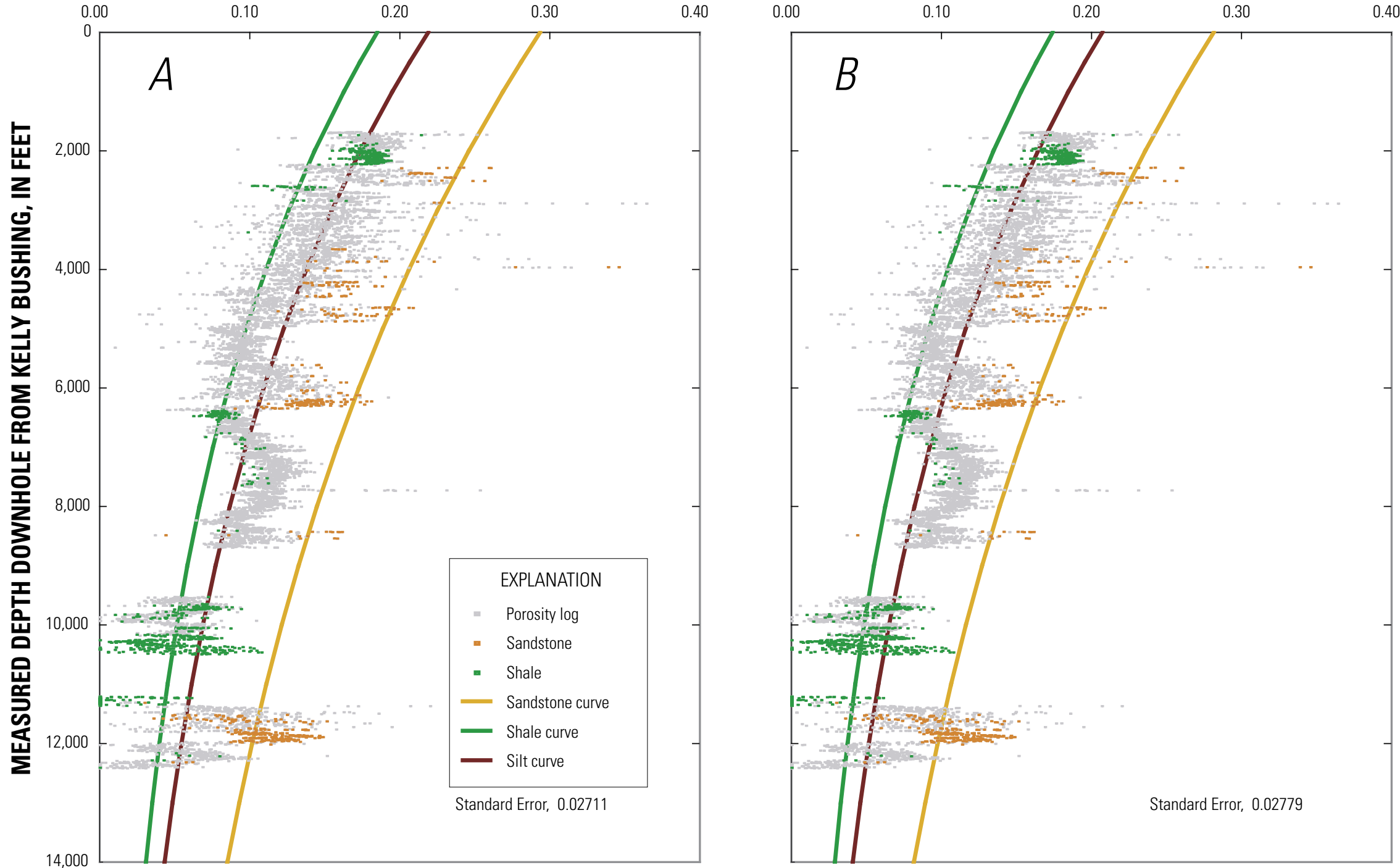

Figure 8. Examples of sonic-porosity log with end-member porosity-depth curves vertically shifted to account for erosion, using best-fit value of $6,025 \mathrm{ft}(A)$ and preferred amount of $6,500 \mathrm{ft}(B)$, chosen to diminish effects of relatively high and potentially erroneous porosities occurring between $\sim 7,500$ - and 8,000-ft depth. Preferred amount of erosion results in a small increase from 0.02711 to 0.02779 in calculated standard error of pore fraction ( 2.5 percent) but arguably improves agreement between most log values and porosity-depth curves. 
Table 3. Exhumation estimates at 145 wellsites on the Alaskan North Slope.

[See figure 1 for location. Asterisk, well used to define compaction parameters]

\begin{tabular}{|c|c|c|c|}
\hline Well & $\begin{array}{c}\text { Latitude } \\
\left({ }^{\circ} \mathrm{N} .\right)\end{array}$ & $\begin{array}{c}\text { Longitude } \\
\quad\left({ }^{\circ} \mathrm{W} .\right)\end{array}$ & $\begin{array}{c}\text { Estimated } \\
\text { exhumation } \\
\text { (ft) }\end{array}$ \\
\hline Akulik \#1 & 69.000253 & 163.479263 & 6,669 \\
\hline Alaska State A-1 & 70.189183 & 146.011848 & 0 \\
\hline Alaska State C-1 & 70.139890 & 146.241640 & 0 \\
\hline Alaska State F-1 & 70.227261 & 146.360470 & 0 \\
\hline Alaska State J-1 & 69.858346 & 146.568318 & 550 \\
\hline Alpenglow 1 & 70.151781 & 147.468380 & 450 \\
\hline Alpine 1 & 70.333210 & 151.010300 & 650 \\
\hline Alpine 3 & 70.366630 & 151.011500 & 800 \\
\hline Amethyst State & 69.543530 & 150.310300 & 4,875 \\
\hline Atigaru Point $1 *$ & 70.552791 & 151.722177 & 650 \\
\hline Aufeis Unit 1 & 69.149937 & 149.571919 & 7,600 \\
\hline Awuna 1 & 69.153205 & 158.022436 & 9,000 \\
\hline Badami 1 & 70.150620 & 147.085030 & 0 \\
\hline Badami 2 & 70.190210 & 147.168590 & 0 \\
\hline Beaufort Sea Block 54-1 & 70.492310 & 147.982150 & 0 \\
\hline Beli Unit 1 & 69.710768 & 146.535486 & 6,500 \\
\hline Bergschrund $1 *$ & 70.352240 & 150.916300 & 700 \\
\hline Big Bend & 69.161959 & 152.267107 & 8,000 \\
\hline Brontosaurus & 70.909018 & 157.245604 & 3,400 \\
\hline Burglin 33-1 & 70.173280 & 148.577590 & 700 \\
\hline Bush Federal & 69.658610 & 149.033330 & 5,800 \\
\hline Canning B-1 & 69.663845 & 146.275276 & 9,525 \\
\hline Cape Halkett $1^{*}$ & 70.767403 & 152.466727 & 525 \\
\hline Colville Delta $1 *$ & 70.476271 & 150.396681 & 525 \\
\hline Colville Delta 2 & 70.472090 & 150.267800 & 250 \\
\hline Colville Delta 3 & 70.437320 & 150.329410 & 300 \\
\hline Colville River & 70.311649 & 150.653900 & 1,000 \\
\hline Colville St 1 & 70.360600 & 150.265280 & 425 \\
\hline Drew Point $1 *$ & 70.879762 & 153.899973 & 1,250 \\
\hline E. de K. Leffingwell & 70.017837 & 146.517428 & 300 \\
\hline Eagle Creek 1 & 68.716878 & 162.549336 & 11,000 \\
\hline East Harrison Bay 1 & 70.492778 & 150.031667 & 450 \\
\hline East Kuparuk Unit 1 & 69.287815 & 150.156460 & 7,000 \\
\hline East Kurupa Unit 1 & 68.846509 & 153.317890 & 9,700 \\
\hline East Mikkelsen Bay 1 & 70.152020 & 146.903010 & 0 \\
\hline East Simpson 1 & 70.917785 & 154.617988 & 1,800 \\
\hline East Simpson 2 & 70.978607 & 154.673874 & 1,800 \\
\hline East Teshekpuk* & 70.569920 & 152.943622 & 1,500 \\
\hline East Umiat & 69.344540 & 151.742690 & 7,000 \\
\hline Echooka Unit & 69.391770 & 148.265700 & 9,000 \\
\hline Fin Creek 1 & 69.500312 & 147.600695 & 8,000 \\
\hline Fiord 2 & 70.381100 & 150.752800 & 400 \\
\hline Fiord 3 & 70.369010 & 150.742700 & 500 \\
\hline Foggy Island 1 & 70.287850 & 147.904250 & 0 \\
\hline Grandstand 1 & 68.966110 & 151.917221 & 8,000 \\
\hline Gubik 1 & 69.422778 & 151.447222 & 5,300 \\
\hline Gubik 2 & 69.432500 & 151.464444 & 5,000 \\
\hline Gull Island 2 & 70.365990 & 148.364250 & 0 \\
\hline Gwydyr Bay & 70.419870 & 149.018060 & 150 \\
\hline Gyr 1 & 69.657070 & 147.279390 & 5,500 \\
\hline Heavenly 1 & 69.729283 & 150.179419 & 3,200 \\
\hline Hemi Springs 3 & 70.136371 & 148.716775 & 650 \\
\hline
\end{tabular}


Table 3. Exhumation estimates at 145 wellsites on the Alaskan North Slope.-Continued

[See figure 1 for location. Asterisk, well used to define compaction parameters]

\begin{tabular}{|c|c|c|c|}
\hline Well & $\begin{array}{c}\text { Latitude } \\
\left({ }^{\circ} \mathrm{N} .\right)\end{array}$ & $\begin{array}{c}\text { Longitude } \\
\left({ }^{\circ} \mathbf{W} .\right)\end{array}$ & $\begin{array}{c}\text { Estimated } \\
\text { exhumation } \\
\text { (ft) }\end{array}$ \\
\hline Iko Bay & 71.170229 & 156.167021 & 2,900 \\
\hline Ikpikpuk 1 & 70.455468 & 154.331330 & 2,325 \\
\hline Inigok $1 *$ & 70.004858 & 153.099126 & 3,225 \\
\hline Itkillik River Unit 1 & 70.065934 & 150.853092 & 1,525 \\
\hline Itkillik Unit 1 & 69.455482 & 150.575587 & 5,500 \\
\hline J. W. Dalton $1^{*}$ & 70.920497 & 153.137526 & 1,200 \\
\hline Kalubik 1 & 70.492430 & 150.275000 & 0 \\
\hline Kalubik Creek 1 & 70.404980 & 150.070240 & 225 \\
\hline Kavik Unit 1 & 69.631846 & 146.569395 & 10,800 \\
\hline Kemik 1 & 69.440511 & 147.269940 & 14,000 \\
\hline Kookpuk 1 & 70.292760 & 150.475140 & 0 \\
\hline Kugrua 1 & 70.587025 & 158.662031 & 3,200 \\
\hline Kuparuk Uplands (Ekvik) & 69.787800 & 150.434100 & 3,000 \\
\hline Kuukpik 3 & 70.462130 & 150.559620 & 800 \\
\hline Kuyanak 1 & 70.931522 & 156.037813 & 2,700 \\
\hline Lake 79 Federal 1 & 70.079742 & 147.767095 & 650 \\
\hline Little Twist & 69.140713 & 152.818461 & 9,000 \\
\hline Long Island 1 & 70.473350 & 149.016120 & 0 \\
\hline Lupine Unit & 69.101180 & 148.618566 & 10,000 \\
\hline Meltwater North 2A & 70.049688 & 150.418557 & 1,800 \\
\hline Mikkelsen Bay St 1 & 70.135190 & 147.197430 & 0 \\
\hline Nanuk 1 & 70.293120 & 150.979100 & 1,350 \\
\hline Narvaq 1 & 69.979200 & 150.116670 & 1,900 \\
\hline Nechelik $1 *$ & 70.392778 & 150.978889 & 650 \\
\hline Niakuk 5 & 70.367620 & 148.194470 & 250 \\
\hline Nora Federal & 69.552059 & 148.752318 & 6,500 \\
\hline North Franklin Bluffs & 70.037110 & 148.684510 & 850 \\
\hline North Inigok 1 & 70.257589 & 152.765982 & 1,850 \\
\hline North Kalikpik $1 *$ & 70.509176 & 152.367868 & 1,525 \\
\hline Northwest Eileen St 1 & 70.365278 & 149.358611 & 200 \\
\hline Nuiqsut 1 & 70.334100 & 151.168900 & 1,300 \\
\hline OCS-Y-1320-1 Crackerjack 1 & 71.418810 & 165.541530 & 0 \\
\hline OCS-Y-0267-1 Fireweed* & 71.087982 & 152.603195 & 350 \\
\hline OCS-Y-0280-1 Antares $1 *$ & 71.035980 & 152.723724 & 325 \\
\hline OCS-Y-0302-1 Mars* & 70.843000 & 152.071800 & 625 \\
\hline OCS-Y-0334-1 Mukluk & 70.683342 & 150.919968 & 375 \\
\hline OCS-Y-0338-1 Phoenix & 70.717216 & 150.427811 & 175 \\
\hline OCS-Y-0742-1 Cabot & 71.324122 & 155.212231 & 1,500 \\
\hline OCS-Y-0804-1 Orion & 70.956180 & 152.062950 & 475 \\
\hline OCS-Y-0996-1 Diamond & 71.332880 & 161.679880 & 2,800 \\
\hline OCS-Y-1413-1 Burger 1 & 71.251390 & 163.194580 & 2,300 \\
\hline OCS-Y-1482-1 Klondike 1 & 70.710880 & 165.249750 & 650 \\
\hline Peard 1 & 70.715647 & 159.000706 & 3,150 \\
\hline Pipeline St 1 & 69.826593 & 148.904421 & 2,800 \\
\hline Placid St & 70.249650 & 148.818850 & 500 \\
\hline Point McIntyre St 3 & 70.390800 & 148.580990 & 300 \\
\hline Point Thomson Unit 1 & 70.174153 & 146.337390 & 0 \\
\hline Point Thomson Unit 2 & 70.163267 & 146.515410 & 0 \\
\hline Point Thomson Unit 3 & 70.172349 & 146.252800 & 0 \\
\hline Prudhoe Bay St 1 & 70.323378 & 148.542250 & 175 \\
\hline Ruby State 1 & 70.054300 & 150.055600 & 1,500 \\
\hline Sag River St 1 & 70.254720 & 148.342470 & 300 \\
\hline
\end{tabular}


Table 3. Exhumation estimates at 145 wellsites on the Alaskan North Slope.

[See figure 1 for location. Asterisk, well used to define compaction parameters]

\begin{tabular}{|c|c|c|c|}
\hline Well & $\begin{array}{c}\text { Latitude } \\
\left({ }^{\circ} \mathrm{N} .\right)\end{array}$ & $\begin{array}{c}\text { Longitude } \\
\left({ }^{\circ} \mathbf{W} .\right)\end{array}$ & $\begin{array}{c}\text { Estimated } \\
\text { exhumation } \\
\text { (ft) }\end{array}$ \\
\hline Schrader Unit 1 & 69.177038 & 151.010910 & 8,000 \\
\hline Seabee 1 & 69.380146 & 152.175335 & 6,500 \\
\hline Sequoia & 70.00995 & 148.99863 & 1,500 \\
\hline Shale Wall Unit & 69.032404 & 150.863605 & 8,000 \\
\hline SOCAL Mobil 33-29E & 70.367390 & 149.396690 & 400 \\
\hline South Barrow 18 & 71.239717 & 156.311421 & 2,700 \\
\hline South Barrow 20 & 71.232505 & 156.336137 & 2,700 \\
\hline South Harrison Bay $1 *$ & 70.422974 & 151.727949 & 625 \\
\hline South Meade 1 & 70.614979 & 156.882605 & 3,350 \\
\hline South Simpson 1 & 70.806667 & 154.981667 & 1,950 \\
\hline Susie Unit & 69.518720 & 148.924740 & 7,000 \\
\hline Tarn 1 & 70.182440 & 150.397070 & 2,000 \\
\hline Tarn 3 & 70.181810 & 150.323300 & 2,000 \\
\hline Tarn 4 & 70.167490 & 150.262500 & 2,000 \\
\hline Temptation 1 & 70.392070 & 151.153100 & 500 \\
\hline Thetis Island 1 & 70.553250 & 150.162950 & 400 \\
\hline Till 1 & 70.401190 & 150.584750 & 700 \\
\hline Toolik Federal 1 & 70.073177 & 148.392870 & 800 \\
\hline Toolik Federal 2 & 70.072018 & 149.206688 & 1,100 \\
\hline Toolik Federal 3 & 70.076431 & 149.900724 & 1,500 \\
\hline Tulaga & 69.703896 & 151.075789 & 4,500 \\
\hline Tulageak 1 & 71.189340 & 155.733573 & 2,600 \\
\hline Tulugak 1 & 68.984812 & 151.329761 & 8,000 \\
\hline Tunalik 1 & 70.205960 & 161.069146 & 3,000 \\
\hline Tungak Creek 1 & 69.883904 & 162.273194 & 5,000 \\
\hline Ugnu & 70.381610 & 149.826060 & 500 \\
\hline W T Foran $1^{*}$ & 70.826847 & 152.285864 & 425 \\
\hline Walakpa 1 & 71.099344 & 156.884339 & 3,325 \\
\hline Walakpa 2 & 71.050003 & 156.952774 & 3,400 \\
\hline West Dease 1 & 71.159068 & 155.629177 & 2,700 \\
\hline West Fish Creek 1 & 70.322002 & 152.065477 & 1,100 \\
\hline West Kavik & 69.770247 & 147.185561 & 3,500 \\
\hline West Kuparuk & 70.335278 & 149.306667 & 650 \\
\hline West Kurupa Unit 1 & 68.882950 & 155.254968 & 7,200 \\
\hline West Mikkelsen St 1 & 70.182240 & 147.378340 & 0 \\
\hline West Mikkelsen St 2 & 70.221825 & 147.190020 & 0 \\
\hline West Sak 4 (25667) & 70.238593 & 149.957774 & 1,200 \\
\hline West Staines 18-9-23 & 70.137553 & 146.388160 & 0 \\
\hline Wolfbutton 25-6-9 & 69.842300 & 149.759880 & 2,500 \\
\hline Wolfbutton $32-7-8$ & 69.920450 & 150.194400 & 2,200 \\
\hline Yukon Gold 1 & 70.041320 & 146.294820 & 700 \\
\hline
\end{tabular}




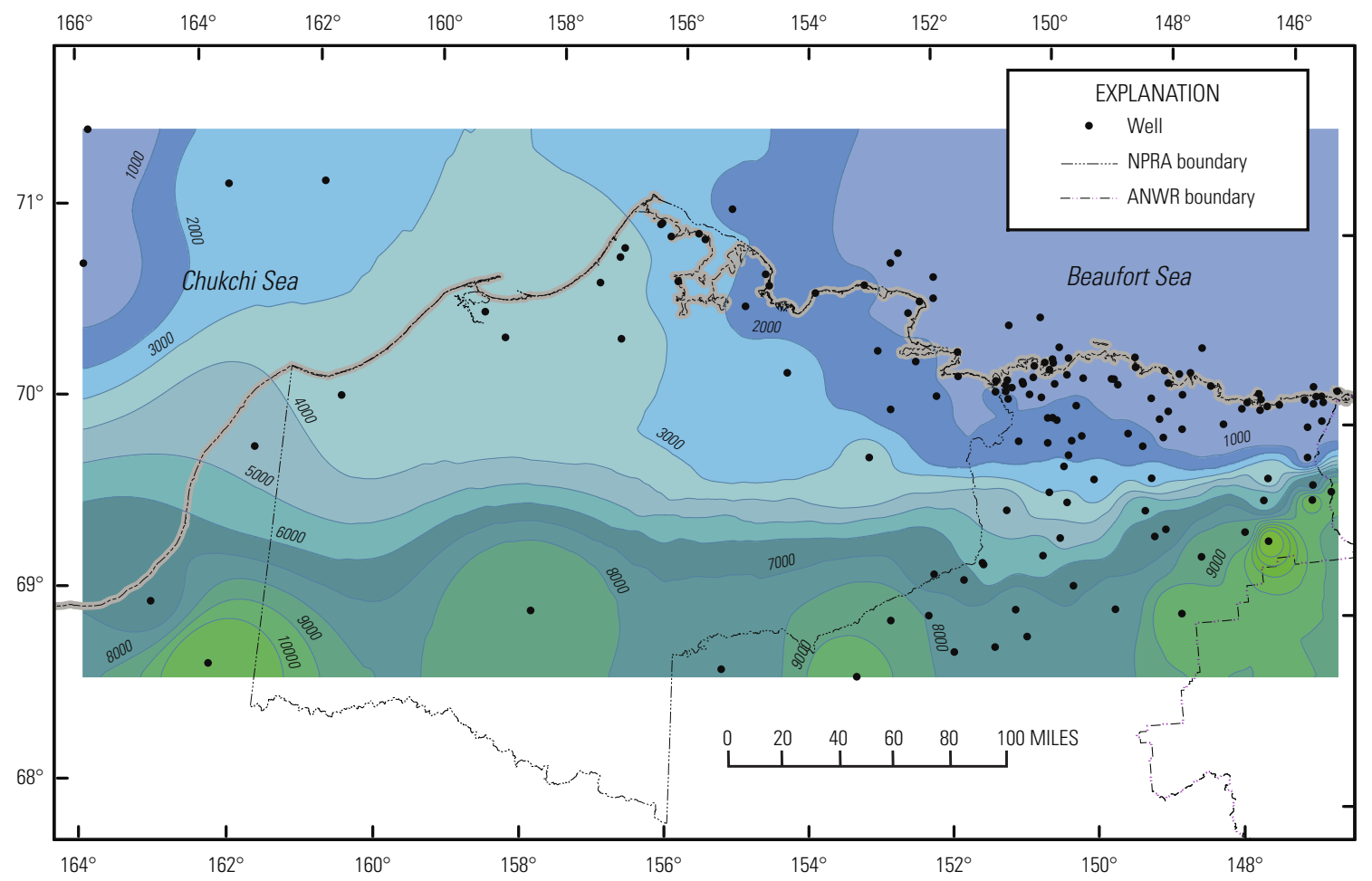

Figure 9. Alaskan North Slope, showing contours (in feet) of estimated amount of exhumation calculated from sonic-porosity logs of wells in study area (fig. 1) and nearby offshore areas. ANWR, Alaska National Wildlife Refuge; NPRA, National Petroleum Reserve in Alaska.

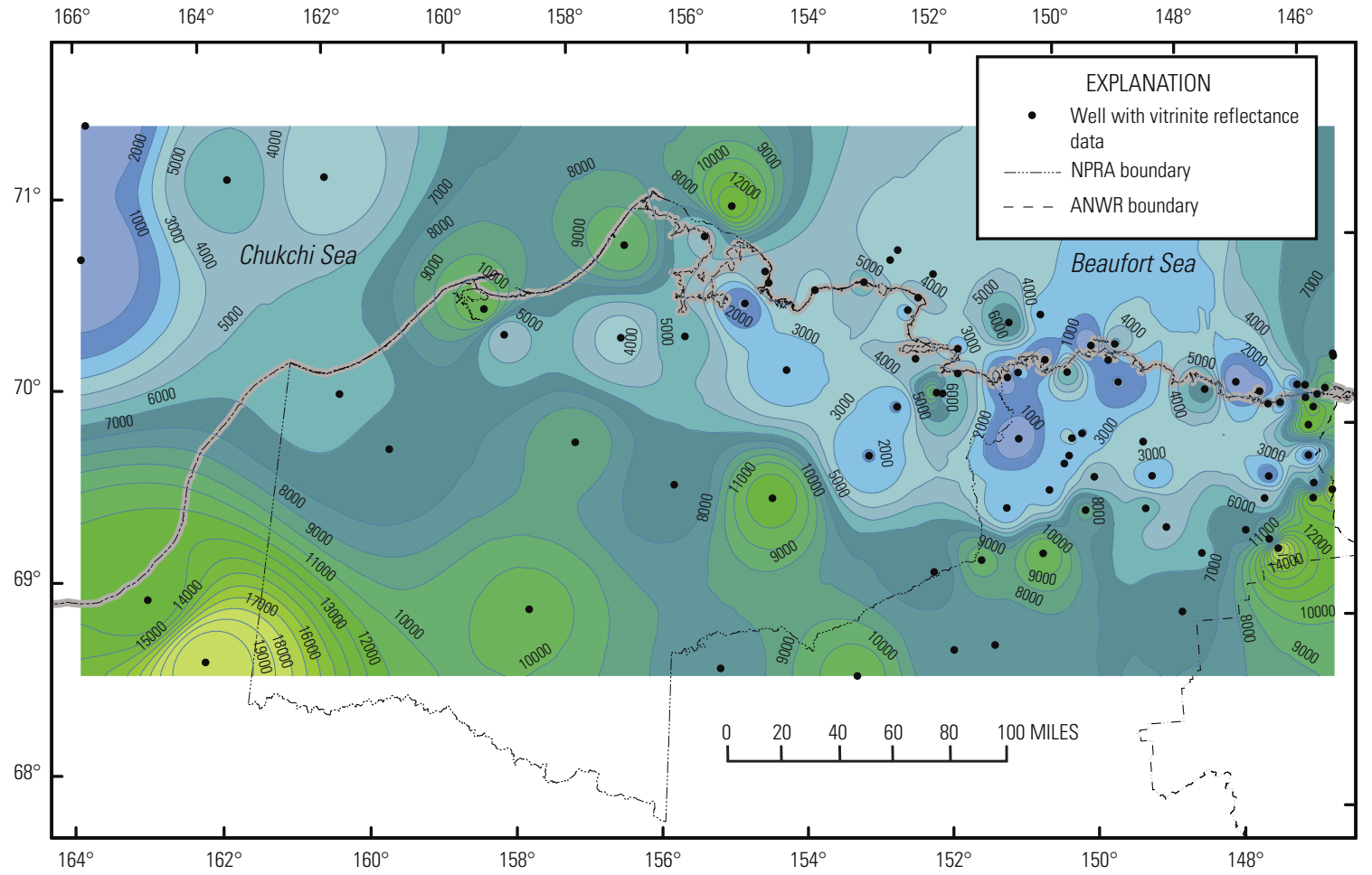

Figure 10. Alaskan North Slope, showing contours (in feet) of estimated amount of exhumation derived from downhole vitrinite-reflectance profiles of wells in study area (figs. 1,3) and nearby offshore areas. ANWR, Arctic National Wildlife Refuge; NPRA, National Petroleum Reserve in Alaska. 
Where fission-track or vitrinite-reflectance data are available to provide alternative exhumation estimates, we compared the various results as another measure of the validity of the sonic-porosity approach to estimating amount of exhumation. Exhumation estimates derived from fission-track analysis, vitrinite-reflectance data, and sonic-porosity logs for the six wells in the Colville Basin for which fission-track analyses have been published (O'Sullivan, 1998) are listed in table 4 . The exhumation estimates derived from fission-track and sonic-porosity data agree within $1,000 \mathrm{ft}$ for four of the six wells and within 1,500 and 2,500 ft, respectively, for the other two wells, Tunalik 1 and Inigok 1 . However, vitrinitereflectance data give more varying results than either of the other methods, despite efforts to remove clearly aberrant data points (for example, recycled vitrinite). In particular, the vitrinite-reflectance method demonstrates gross discrepancies of many thousands of feet relative to alternative methods for the Walakpa 1 and Alaska State C-1 wells. Both wells lie near the Alaska coastline, the Walakpa 1 well on Point Barrow and the Alaska State $\mathrm{C}-1$ well adjacent to the northwest corner of the Alaska National Wildlife Refuge (fig. 1). Neither of these wells is located on a structural feature likely to produce such large amounts of exhumation. Moreover, the Alaska State C -1 well penetrates several thousand feet of strata deposited coincident with and subsequent to the latest known exhumation event in the basin (O'Sullivan, 1999) and so the stratigraphic evidence from this well suggests that little or no exhumation occurred in that area. Thus, the large amount of exhumation indicated by vitrinite-reflectance trends for the Walakpa 1 and Alaska State $\mathrm{C}-1$ wells is unlikely, and lower exhumation estimates consistent with the fission-track and sonic-porosity data are preferred.

For this small set of wells with published fission-track analyses, the amounts of exhumation estimated from fissiontrack data and sonic-porosity logs appear to be more reliable than those estimated from vitrinite-reflectance profiles. The absence of fission-track data for other wells in the Colville Basin (fig. 1) precludes more extensive comparison of all three methods. However, comparison of the exhumation estimates from sonic-porosity and vitrinite-reflectance data in other wells further exemplifies the advantages of the sonic-porosity approach. Contours of exhumation in the study area (fig. 1) created by interpolation of values estimated from borehole vitrinite-reflectance trends are mapped in figure 10. For each well from which vitrinite-reflectance data are available, the amount of exhumation was estimated by the trendline-projection method of Dow (1977). A vitrinite reflectance of 0.2 percent was assumed for the surface value at the time of maximum burial, in accordance with typical surface values cited by other workers (for example, Hunt, 1979; Armagnac and others, 1989). Spurious data points and obvious irregularities in the vitrinite-reflectance data were removed to provide the best possible estimates.

In comparison with figure 9, figure 10 demonstrates similar regional trends, such as increasing amounts of exhumation toward the southern foothills and decreasing amounts toward the
Table 4. Comparison of exhumation estimates for the Colville Basin, northern Alaska, derived from fission-track analysis (O'Sullivan, 1998), vitrinite-reflectance data (Johnsson and others, 1999), and sonic-porosity logs (this study)

[Amount of exhumation was estimated by projecting log-linear best-fit curve for vitrinite reflectance $\left(R_{0}\right)$ versus depth, assuming that paleosurface at time of maximum burial coincided with $R_{0}=0.2$ (Dow, 1977)]

\begin{tabular}{lccc}
\hline \multirow{2}{*}{ Well } & \multicolumn{3}{c}{ Exhumation estimate (ft) } \\
\cline { 2 - 4 } & $\begin{array}{c}\text { Fission } \\
\text { track }\end{array}$ & $\begin{array}{c}\text { Vitrinite } \\
\text { reflectance }\end{array}$ & $\begin{array}{c}\text { Sonic } \\
\text { porosity }\end{array}$ \\
\hline Alaska State C-1 & 0 & ${ }^{1} 10,261$ & 0 \\
Inigok 1 & 5,577 & 1,989 & 3,225 \\
Kemik 2 & 17,388 & 17,605 & ${ }^{2} 17,800$ \\
Seabee 1 & 6,890 & 6,456 & 6,500 \\
Tunalik 1 & 4,265 & 5,321 & 3,000 \\
Walakpa 1 & 3,937 & 9,702 & 3,325 \\
\hline
\end{tabular}

${ }^{1}$ No vitrinite-reflectance data available; estimate derived from the Alaska State D-1 well, $4.5 \mathrm{mi}$ away.

${ }^{2}$ Estimated by stratigraphic extrapolation from the Kemik 1 well, $4.5 \mathrm{mi}$ away.

northwestern and northeastern offshore areas. Yet relative to the smooth gradients shown in figure 9 , figure 10 displays a marked irregularity between wells, and in the coastal areas, the predicted amounts of exhumation generally are substantially greater than those determined from sonic-porosity data (fig. 9; table 3). Given that the stratigraphic and fission-track data (for example, Bird and Molenaar, 1992; O'Sullivan, 1999) agree with the sonic-porosity data, the sonic-porosity approach appears to provide more accurate results, as well as being more consistent between wells, than the vitrinite-reflectance approach.

\section{Conclusion}

Restoration of original depositional thicknesses of basin fill in partially exhumed basins is a fundamental problem in constructing burial-history models. We have developed an approach to estimating the eroded thickness across a basin by using widely available borehole geophysical logs. In the Colville Basin (fig. 1), our method produces results similar to those from fission-track analysis, but the greater availability of geophysical logs relative to fission-track data allows a higher spatial resolution in the exhumation estimates presented here than in published fission-track studies. However, results from both the fission-track method and our sonic-porosity approach commonly contrast markedly with those from vitrinite-reflectance data. Furthermore, the vitrinite-reflectance data are demonstrably unreliable predictors of amounts of exhumation, yielding estimates that are inconsistent from one place to the next (fig. 10) and, in many places, inaccurate. In the Colville 
Basin, a burial-history model based on vitrinite-reflectancederived exhumation estimates clearly will not reflect a reasonable basin evolution, whereas a model based on sonic-porosity-derived exhumation estimates, as mapped in figure 9, will depict a much more plausible one.

The implications of this study for basin modeling elsewhere are unclear with regard to model accuracy. The reliability of vitrinite-reflectance data for estimating amount of exhumation may not be a significant concern in many basins, and so these data could provide exhumation estimates with similar or greater accuracy than those from sonic-porosity logs. However, a significant advantage of the sonic-porosity approach is that the data are independent of the thermal evolution of the basin. Fission-track and vitrinite-reflectance data, in contrast, are paleotemperature indicators that require assumed values for thermal gradient or heat flow and thermal conductivity to calculate the stratigraphic thicknesses of denuded sections. Therefore, our approach uniquely results in thermal-history models in which burial-history parameters are independent variables, simplifying the modeling process and reducing overall uncertainty.

\section{References Cited}

Armagnac, C., Bucci, J., Kendall, C.G.S.C., and Lerche, I., 1989, Estimating the thickness of sediment removed at an unconformity using vitrinite reflectance data, in Naeser, N.D., and McCulloh, T.H., eds., Thermal history of sedimentary basins; methods and case histories: New York, Springer-Verlag, p. 217-238.

Athy, L.F., 1930, Density, porosity, and compaction of sedimentary rocks: American Association of Petroleum Geologists Bulletin, v. 14, no. 1, p. 1-24.

Bird, K.J., 1988a, Alaskan North Slope stratigraphic nomenclature and data summary for government-drilled wells, in Gryc, G., ed., Geology and exploration of the National Petroleum Reserve in Alaska, 1974 to 1982: U.S. Geological Survey Professional Paper 1399, p. 317-353.

Bird, K.J., 1988b, Structure-contour and isopach maps of the National Petroleum Reserve in Alaska, in Gryc, G., ed., Geology and exploration of the National Petroleum Reserve in Alaska, 1974 to 1982: U.S. Geological Survey Professional Paper 1399, p. 355-377.

Bird, K.J., and Andrews, J., 1979, Subsurface studies of the Nanushuk Group, North Slope, Alaska, in Ahlbrandt, T.S., ed., Preliminary geologic, petrologic, and paleontologic results of the study of Nanushuk Group rocks, North Slope, Alaska: U.S. Geological Survey Circular 794, p. 32-41.

Bird, K.J., Burruss, R. C., and Pawlewicz, M.J., 1998, Thermal maturity, in ANWR Assessment Team, ed., The oil and gas resource potential of the Arctic National Wildlife Refuge 1002 area, Alaska: U.S. Geological Survey OpenFile Report 98-34, p. VR1-VR19.
Bird, K.J., and Molenaar, C.M., 1992, The North Slope foreland basin, Alaska, in Macqueen, R., and Leckie, D., eds., Foreland basins and fold belts: American Association of Petroleum Geologists Memoir 55, p. 363-393.

Bray, R.J., Green, P.F., and Duddy, I.R., 1992, Thermal history reconstruction using apatite fission track analysis and vitrinite reflectance; a case study from the UK East Midlands and southern North Sea, in Hardman, R.F.P., ed., Exploration Britain; geological insights for the next decade: Geological Society of London Special Publication 67, p. 2-25.

Deming, D., Nunn, J.A., Jones, S., and Chapman, D.S., 1990, Some problems in thermal history studies, in Nuccio, V.F., and Barker, C.E., eds., Applications of thermal maturity studies to energy exploration: Denver, Colo., Society of Economic Paleontologists and Mineralogists, p. 61-80.

Dow, W.G., 1977, Kerogen studies and geological interpretations: Journal of Geochemical Exploration, v. 7, no. 2, p. 79-99.

Falvey, D.A., and Middleton, M.F., 1981, Passive continental margins; evidence for a prebreakup deep crustal metamorphic subsidence mechanism: Oceanologica Acta, v. 4 (supp.), p. 103-114.

Grantz, A., and May, S.D., 1988, Regional geology and petroleum potential of the United States Chukchi shelf north of Point Hope, in Gryc, G., ed., Geology and exploration of the National Petroleum Reserve in Alaska, 1974 to 1982: U.S. Geological Survey Professional Paper 1399, p. 209-229.

Green, P.F., Duddy, I.R., and Bray, R.J., 1995, Application of thermal history reconstruction in inverted basins, in Buchanan, J.G., and Buchanan, P.G., eds., Basin inversion: Geological Society of London Special Publication 88, p. 149-165.

Hedberg, H.D., 1936, Gravitational compaction of clays and shales: American Journal of Science, v. 31, no. 184, p. 241-287.

Houseknecht, D.W., 2003, Brookian stratigraphic plays in the National Petroleum Reserve-Alaska (NPRA): U.S. Geological Survey Open-File Report 03-39, 19 p.

Houseknecht, D.W., and Hayba, D.O., 1998, Modeling oil generation in the undeformed part of the Arctic National Wildlife Refuge 1002 area, in ANWR Assessment Team, ed., The oil and gas resource potential of the Arctic National Wildlife Refuge 1002 area, Alaska: U.S. Geological Survey Open-File Report 98-34, p. HG1-HG24.

Hunt, J.M., 1979, Petroleum geochemistry and geology: San Francisco, W.H. Freeman, 617 p. 
Hunt, J.M., Whelan, J.K., Eglinton, L.B., and Cathles, L.M., III, 1998, Relation of shale porosities, gas generation, and compaction to deep overpressures in the U.S. Gulf Coast, in Law, B.E., Ulmishek, G.F., and Slavin, V.I., eds., Abnormal pressures in hydrocarbon environments: American Association of Petroleum Geologists Memoir 70, p. 87-104.

Issler, D.R., 1992, A new approach to shale compaction and stratigraphic restoration, Beaufort-Mackenzie Basin and Mackenzie Corridor, Northern Canada: American Association of Petroleum Geologists Bulletin, v. 76, p. 1170-1189.

Johnsson, M.J., Evans, K.R., and Marshall, H.A., 1999, Thermal maturity of sedimentary rocks in Alaska; digital resources: U.S. Geological Survey Digital Data Series DDS-54, CD-ROM.

Magara, K., 1976, Thickness of removed sedimentary rocks, paleopore pressure, and paleotemperature, southwestern part of Western Canada basin: American Association of Petroleum Geologists Bulletin, v. 60, no. 4, p. 554-565.

Magara, K., 1980, Comparison of porosity-depth relationships of shale and sandstone: Journal of Petroleum Geology, v. 3, no. 2 , p. $175-185$.

Molenaar, C.M., 1985, Subsurface correlations and depositional history of the Nanushuk Group and related strata, North Slope, Alaska, in Huffman, A.C., ed., Geology of the Nanushuk Group and related rocks, North Slope, Alaska: U.S. Geological Survey Bulletin 1614, p. 37-60.

Nelson, P.H., Kibler, J.E., and Giberson, C.P., 1998, Well data and well plots, in ANWR Assessment Team, ed., U.S. Geological Survey Open-File Report 98-34, p. WL1-WL84.
Nelson, P.H., and Bird, K.J., 2005, Porosity compaction trends and regional uplift derived from sonic logs, National Petroleum Reserve, Alaska: U.S. Geological Survey Scientific Investigations Report 2005-5051, 24 p.

O’Sullivan, P.B., 1996, Late Mesozoic and Cenozoic theromotectonic evolution of the Colville Basin, North Slope, Alaska, in Johnsson, M.J., and Howell, D.G., eds., Thermal evolution of sedimentary basins in Alaska: U.S. Geological Survey Bulletin 2142, p. 45-79.

O’Sullivan, P.B., 1999, Thermochronology, denudation and variations in palaeosurface temperature; a case study from the North Slope foreland basin, Alaska: Basin Research, v. 11, no. 3, p. 191-204.

Raiga-Clemenceau, J., Martin, J.P., and Nicoletis, S., 1988, The concept of acoustic formation factor for more accurate porosity determination from sonic transit time data: Log Analyst, v. 29, no. 1, p. 54-60.

Rowan, E.L., Hayba, D.O., Nelson, P.H., Burns, W.M., and Houseknecht, D.W., 2003, Sandstone and shale compaction curves derived from sonic and gamma ray logs in offshore wells, North Slope, Alaska-parameters for basin modeling: U.S. Geological Survey Open-File Report 03-329, 3 sheets.

Sherwood, K.W., Craig, J.D., Lothamer, R.T., Johnson, P.P., and Zerwick, S.A., 1998, Chukchi shelf assessment province, in Sherwood, K.W., ed., Undiscovered oil and gas resources, Alaska Federal offshore (as of January 1995): U.S. Minerals Management Service OCS Monograph MMS 98-0054, p. 115-196. 